\title{
Ultrastructural Localization of Concanavalin A Surface Receptors on Brush-Border Enterocytes in Normal Children and during Coeliac Disease
}

\author{
DANIEL VASMANT, GERARD FELDMANN, ${ }^{(28)}$ AND JEAN-LOUP FONTAINE \\ Laboratoire d'Histologie, Embryologie, Cytogénétique, Faculté de Médecine Xavier-Bichat, 75018 Paris and \\ Service de Pédiatrie, Hôpital Trousseau, 75012 Paris, France
}

\section{Summary}

Concanavalin A surface receptors were detected on brush border enterocytes from child intestinal biopsies by the concanavalin Aperoxidase method. On electron microscopy, these receptors appeared as electron-dense deposits, located on a band running along the innermost part of the brush border membrane glycocalyx. In the five control subjects tested, brush border length was $1.06 \pm$ $0.18 \mu \mathrm{m}$, and band thickness, $19 \pm 4 \mathrm{~nm}$. Deposits were regular in shape and evenly spaced out along the entire membrane, reflecting homogeneous glycosylation of the normal brush border. In seven patients with villous atrophy induced by gluten, the brush border was damaged and its length was $1.04 \pm 0.39 \mu \mathrm{m}$. The thickness of the electron-dense deposit band was $19 \pm 6 \mathrm{~nm}$; deposit shape was irregular and the band ran discontinuously along the membrane. The degree of this abnormality seemed to correspond to the degree of brush border damage. In six treated coeliac patients with normalized mucosa, the brush border was structurally normal but it was significantly longer $(1.25 \pm 0.32 \mu \mathrm{m})$ than in the controls $(p<0.01)$. The electron-dense band was significantly thinner $(16$ $\pm 7 \mathrm{~nm})$ than in the controls $(p<0.01)$. The distribution of the electron-dense deposits was sporadic in some parts of the band and regular in others. These results suggest abnormal glycosylation of the brush border membrane in coeliac disease, and might be due to the presence of abnormal glycoconjugates. It remains to be established if these changes are induced by gluten toxicity or are the consequences of nonspecific intestinal disorders.

\section{Speculation}

Glycoconjugates are the most important component of the brush border glycocalyx. During gluten-induced villous atrophy, the most mature enterocytes exhibit an abnormal glycocalyx. We therefore investigated coeliac and noncoeliac patients by the concanavalin A-peroxidase method in order to examine brush border enterocyte glycoconjugates by electron microscopy.

During villous atrophy in children with coeliac disease, both the number of damaged enterocytes and the cell turnover rate increase (27). The mechanisms of these changes are still controversial. No peptidase deficiency has ever been proved (19), but most authors agree that a local immunological reaction is involved $(11,22,24)$. However, the way in which gluten starts this reaction is not known. Recently, Douglas (3) showed that gluten adherence increased on isolated brush border (BB) from coeliac intestinal biopsies. Weiser and Douglas (26) observed a decline in glycosyltransferase activity of the same BB. On the basis of these findings both authors suggested the presence of an abnormal glycoprotein on the BB membrane in coeliac disease (25). Earlier conventional ultrastructural studies had already revealed the presence of abnormal microvilli during gluten-induced villous atrophy $(1,20,21$, 23 ), but the abnormalities disappeared when the villi were nor- malized by a completely gluten-free diet $(21,23)$. Nevertheless, to our knowledge, no ultrastructural cytochemical study of the BB membrane has been yet made for the purpose of investigating glycoconjugates.

With this view, we applied the concanavalin A-peroxidase method to biopsies from children displaying no clinical or histologic evidence of small bowel involvement, and from coeliac patients at various stages of their illness. Concanavalin A (Con A) is a lectin from Canavalia Enseformis, which binds specifically to $\alpha$-D-glucopyranosyl, $\alpha$-D-fructopyranosyl, and $\alpha$-D-manopyranosyl (6). Covalent linkage between Con A and horseradish peroxidase was easily obtained (2). Peroxidase was revealed on electron microscopy by the Graham and Karnovsky technique (7). Electron-dense deposits showed the distribution of the above three carbohydrates involved in the formation of BB membrane glycoproteins and glycolipids $(9,12)$.

\section{MATERIALS AND METHODS}

Patients. Three groups of patients were studied. Group I comprised five patients who acted as controls. All biopsies were from patients with no clinical or biochemical symptoms of malabsorption and were strictly normal on light microscopy. Table 1 gives patients' age and the reasons for their hospitalization.

Group II consisted of seven patients with active coeliac disease and villous atrophy (VA), whose diet included gluten. The degree of VA was assessed by light microscopy and was found to be subtotal in four cases and partial in three times. Coeliac disease (CD) was diagnosed on the basis of the E.S.P.G.A.N. criteria (14). When the disease was discovered after the age of 2 years, the gluten challenge was not always performed, but VA disappeared after 1 year on a gluten free diet, thus confirming the diagnosis of $\mathrm{CD}(4)$. Table 2 summarizes the characteristics of group II patients.

Group III included six CD patients on a completely gluten-free diet displaying normal mucosa on light microscopy. In this group, some biopsies were analyzed after an initial period of gluten-free (from 6 months to 3 years 9 months) and others, after a second period of such diet (from 1 year to 1 year 7 months), following a positive gluten challenge. $C D$ diagnosis was based on the same criteria as those applied to group II. Table 3 summarizes the features of group III patients.

Methods. Intestinal biopsies were collected by Crosby capsule. Radioscopic checking of the capsule's position ensured that it remained at Treitz's angle. Each biopsy was divided into two parts. One part was fixed for light microscopy in Bouin's fluid and embedded in paraffin; $5 \mu \mathrm{m}$-thick sections were cut and stained with hematein-phloxine-safran and PAS. The other part of the biopsy was processed for ultrastructural cytochemical study as previously described (8). The intestinal tissue was fixed at $+4^{\circ} \mathrm{C}$ for $2 \mathrm{hr}$ in a solution of $2.5 \%$ glutaraldehyde, buffered with $0.1 \mathrm{M}$ phosphate buffer, $\mathrm{pH} 7.3$, and washed in $0.1 \mathrm{M}$ phosphate buffer, $\mathrm{pH}$ 7.3. The fragment was cut into $1 \mathrm{~mm}^{3}$ blocks with a razor 
blade and incubated with Con A (I.B.F., Clichy, France) at a concentration of 100 or $200 \mu \mathrm{g} / \mathrm{ml}$ for $4 \mathrm{hr}$ at room temperature. After washing, blocks were placed in physiologic buffered saline (PBS) and incubated with horseradish peroxidase (RZ 3.0, Sigma Chemical Company, St Louis, MO) at a concentration of $100 \mu \mathrm{g} /$ $\mathrm{ml}$ for $2 \mathrm{hr}$. After washing for $12 \mathrm{hr}$ in PBS, peroxidase was revealed by the technique of Graham and Karnovsky (7). For control reactions, some blocks were incubated either with Con A and its specific inhibitor $\alpha$-methyl-D-mannoside (Merck, Darmstadt, West Germany) at a concentration of 0.2 mole/liter, or without Con A but with peroxidase alone or with only the Graham and Karnovsky's solution (7). Blocks were postfixed in 2\% osmium tetroxide solution buffered with veronal acetate buffer at $\mathrm{pH} 7.2$ for $30 \mathrm{~min}$ and dehydrated by graded alcohols. After orientation in a flat plastic sheet, blocks were embedded in epoxy resin. The thick sections were examined with a light microscope and the unstained ultrathin sections, with an electron microscope (Siemens Elmiskop IA Electron Microscope, Berlin, West Germany). Some ultrathin sections were stained with lead citrate. For quantification, final magnifications of $\times 60,000$ and $\times 120,000$ were used. The electron microscope was previously tested with a reference grid (Ladd Research Industries, Inc., Burlington, VT). For each biopsy $2-5$ villi were randomly photographed. When there was a VA, 2-5 superficial areas were also studied at random. Ten enterocytes located in the top part of villi and cut longitudinally

Table 1. Control patients

\begin{tabular}{ccl}
\hline Patients & Age yr/mo & \multicolumn{1}{c}{ Clinical data } \\
\hline 1 & $6 / 10$ & Failure to thrive \\
2 & $2 / 1$ & Failure to thrive \\
3 & $0 / 11$ & Recurrent diarrhea \\
4 & $2 / 5$ & Recurrent diarrhea \\
5 & $1 / 0$ & Failure to thrive \\
\hline
\end{tabular}

were studied on micrographs. The following features were studied: (1) microvilli (MV) length on $5 \mathrm{MV}$ from each enterocyte; (2) MV structure (dissimilarity, variable diameter and length were considered abnormal parameters); (3) the thickness of the electron-dense deposits along the middle of the lateral MV membrane. Five measurements were made on each MV with a ruler and magnifying glass on prints magnified at $\times 120,000$. Fifty measurements were made for each biopsy. The precision of the measurements was estimated at $0.25 \mathrm{~mm}$, i.e., $2 \mathrm{~nm}$ for this magnification; and (4) the regularity of the shape and distribution of the electrondense deposits.

Statistical analysis was performed with Student's $t$ test.

\section{RESULTS}

Light microscopy. On the thick sections from group I patients (controls), dark brown deposits were only found on the $\mathrm{BB}$ of enterocytes located on the top third of the villi. There were no deposits at the base of the villi, in the crypts or inside the enterocytes. Similar features were observed in sections from coeliac patients (group II and III), whatever the concentration of Con A used. With the inhibitor ( $\alpha$-methyl-D-mannoside) deposits were generally absent; a few were found because inhibition was not always complete (2). No dark brown deposits were observed on blocks incubated with peroxidase alone or in the Graham and Karnovsky solution.

Electron microscopy. In group I, the length of MV was $1.06 \pm$ $0.18 \mu \mathrm{m}$ (mean \pm S.D.) and their structure was normal of slightly damaged (Table 4). The electron-dense deposits indicating the presence of Con A surface receptors were visible outside the membrane as an external band divided in two parts: an inner part, homogeneous and moderately electron-dense, and an outer part, composed of electron-dense particles (Fig. 1). This band formed a coating adjacent to the trilaminary membrane, as shown by lead citrate staining of ultrathin sections (Fig. 2). Total deposit thick-

Table 2. Patients with active coeliac disease and villous atrophy (VA) on a diet including gluten

\begin{tabular}{|c|c|c|c|c|}
\hline Patients & $\begin{array}{c}\text { Age at VA diagnosis } \\
(\mathrm{yr} / \mathrm{mo})\end{array}$ & $\begin{array}{c}\text { Age at the } \\
\text { present biopsy } \\
(\mathrm{yr} / \mathrm{mo})\end{array}$ & Gluten challenge' & $\begin{array}{l}\text { Histologic results of } \\
\text { the present biopsy }\end{array}$ \\
\hline 1 & $1 / 6$ & $5 / 0$ & + & $\mathrm{SVA}^{2}$ \\
\hline 2 & $16 / 6$ & $17 / 0$ & 0 & SVA \\
\hline 3 & $10 / 7$ & $10 / 7$ & 0 & SVA \\
\hline 4 & $3 / 10$ & $4 / 4$ & 0 & SVA \\
\hline 5 & $4 / 6$ & $6 / 4$ & + & $\mathrm{PVA}^{3}$ \\
\hline 6 & $0 / 6$ & $5 / 11$ & + & PVA \\
\hline 7 & $0 / 11$ & $6 / 4$ & + & PVA \\
\hline
\end{tabular}

\footnotetext{
$1+$, the gluten challenge showed relapse of VA; 0 , no gluten challenge was performed as the patient was over 2 years old when VA was discovered.
} Further intestinal biopsy after a period of gluten-free diet showed normal mucosa.

${ }^{2}$ SVA, subtotal villous atrophy.

${ }^{3}$ PVA, partial villous atrophy.

Table 3. Patients with treated coeliac disease and normalized mucosa

\begin{tabular}{|c|c|c|c|c|}
\hline Patients & $\begin{array}{c}\text { Age at } \mathrm{VA}^{1} \text { diagnosis } \\
(\mathrm{yr} / \mathrm{mo})\end{array}$ & $\begin{array}{c}\text { Age at VA } \\
\text { present biopsy } \\
(\mathrm{yr} / \mathrm{mo})\end{array}$ & Gluten challenge $^{2}$ & $\begin{array}{l}\text { Duration of gluten-free } \\
\text { diet prior to the pre- } \\
\text { sent biopsy } \\
(\mathrm{yr} / \mathrm{mo})\end{array}$ \\
\hline 1 & $14 / 1$ & $18 / 0$ & + & $1 / 7$ \\
\hline 2 & $1 / 6$ & $6 / 0$ & + & $1 / 0$ \\
\hline 3 & $1 / 2$ & $8 / 6$ & + & $1 / 0$ \\
\hline 4 & $1 / 1$ & $5 / 8$ & + & $1 / 0$ \\
\hline 5 & $2 / 2$ & $6 / 2$ & 0 & $3 / 9$ \\
\hline 6 & $11 / 2$ & $11 / 8$ & 0 & $0 / 6$ \\
\hline
\end{tabular}

\footnotetext{
${ }^{1} \mathrm{VA}$, villous atrophy.

${ }^{2}+$, the present biopsy was performed after a period of gluten-free diet following a positive gluten challenge; 0 , no gluten was performed as the patient was more than 2 years old when the VA was discovered. The present biopsy was performed after a first period of gluten-free diet.
} 
Table 4. Electron microscopic findings in groups $I, I I$ and $I I I$

\begin{tabular}{|c|c|c|c|c|}
\hline Group & $\begin{array}{l}\text { Total number } \\
\text { of values }\end{array}$ & $\begin{array}{c}\text { Length of } \\
\text { microvilli }(\mu \mathrm{m}) \\
\text { (mean } \pm \text { S.D. })\end{array}$ & $\begin{array}{l}\text { Thickness of } \\
\text { electron-dense } \\
\text { deposits (nm) } \\
\text { (mean } \pm \text { S.D.) }\end{array}$ & $\begin{array}{c}\text { Appearance of } \\
\text { electron-dense deposits }\end{array}$ \\
\hline $\begin{array}{c}\mathrm{I} \\
\text { (control patients) }\end{array}$ & 250 & $1.06 \pm 0.18$ & $19 \pm 4$ & $\begin{array}{l}\text { Regularly in shape, evenly spaced out } \\
\text { over the entire membrane }\end{array}$ \\
\hline $\begin{array}{c}\text { II } \\
\text { (patients with villous atrophy) }\end{array}$ & 350 & $1.04 \pm 0.39^{2}$ & $19 \pm 6^{2}$ & $\begin{array}{l}\text { Irregular in shape unevenly spaced out } \\
\text { over the membrane }\end{array}$ \\
\hline $\begin{array}{l}\text { III } \\
\text { (patients with normalized mu- } \\
\text { cosa) }\end{array}$ & 300 & $1.25 \pm 0.32^{3}$ & $16 \pm 7^{3}$ & $\begin{array}{l}\text { Irregular and discontinuous in some } \\
\text { parts of the deposit band, regular } \\
\text { and continuous in others }\end{array}$ \\
\hline
\end{tabular}

'Five measurements were made on one enterocyte; 10 enterocytes were studied for each patient. Fifty measurements were made for each biopsy.

${ }^{2} \mathrm{P}>0.05$ between groups I and II.

${ }^{3} \mathrm{P}<0.01$ between groups I and III.

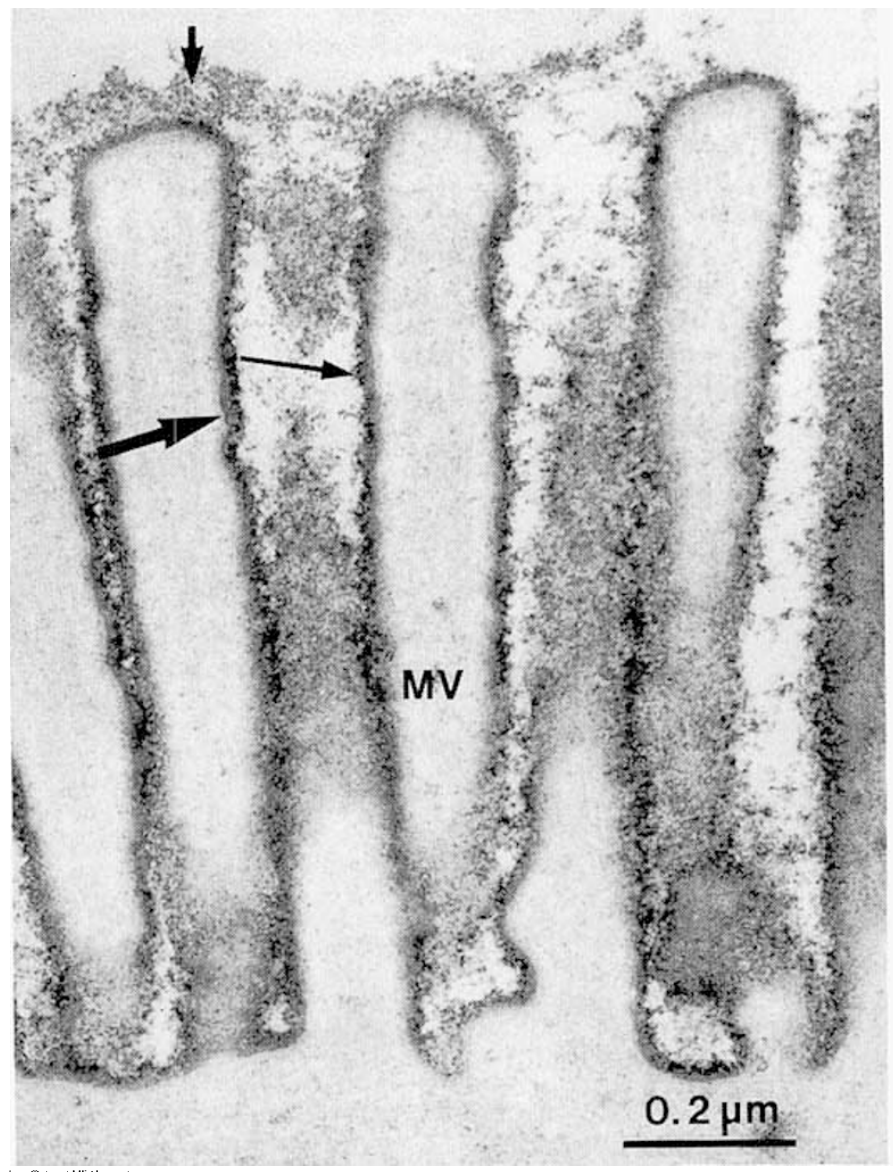

Fig. 1. Control patients (group I). Ultrastructural appearance of the enterocyte brush border membrane. Concanavalin A surface receptors appear as electron-dense deposits located on an external continuous band of microvilli (MV). This band is regular in shape, evenly spaced out on the entire membrane. Two parts are visible: an inner part homogeneous and moderately electron-dense (large arrow) and an outer part composed of electron-dense particles (thin arrow). The cell surface coat is also visible (short arrow) (Ultrathin sections not stained with lead citrate) $(\times 85,000)$.

ness was $19 \pm 4 \mathrm{~nm}$ (mean \pm S.D.) (Table 4). MV varied little. They were generally regular in shape and distribution. The electron-dense deposits were found along a continuous homogeneous band, extending along the entire MV membrane. On some MV from patient 2, some small irregularly shaped areas were found. Surface coat filaments on the upper part of the MV were sometimes stained, but often totally absent (Fig. 1).

In group II, the length of the MV was $1.04 \pm 0.39 \mu \mathrm{m}$ (mean \pm S.D.) (Table 4) and their structure was observed to be very

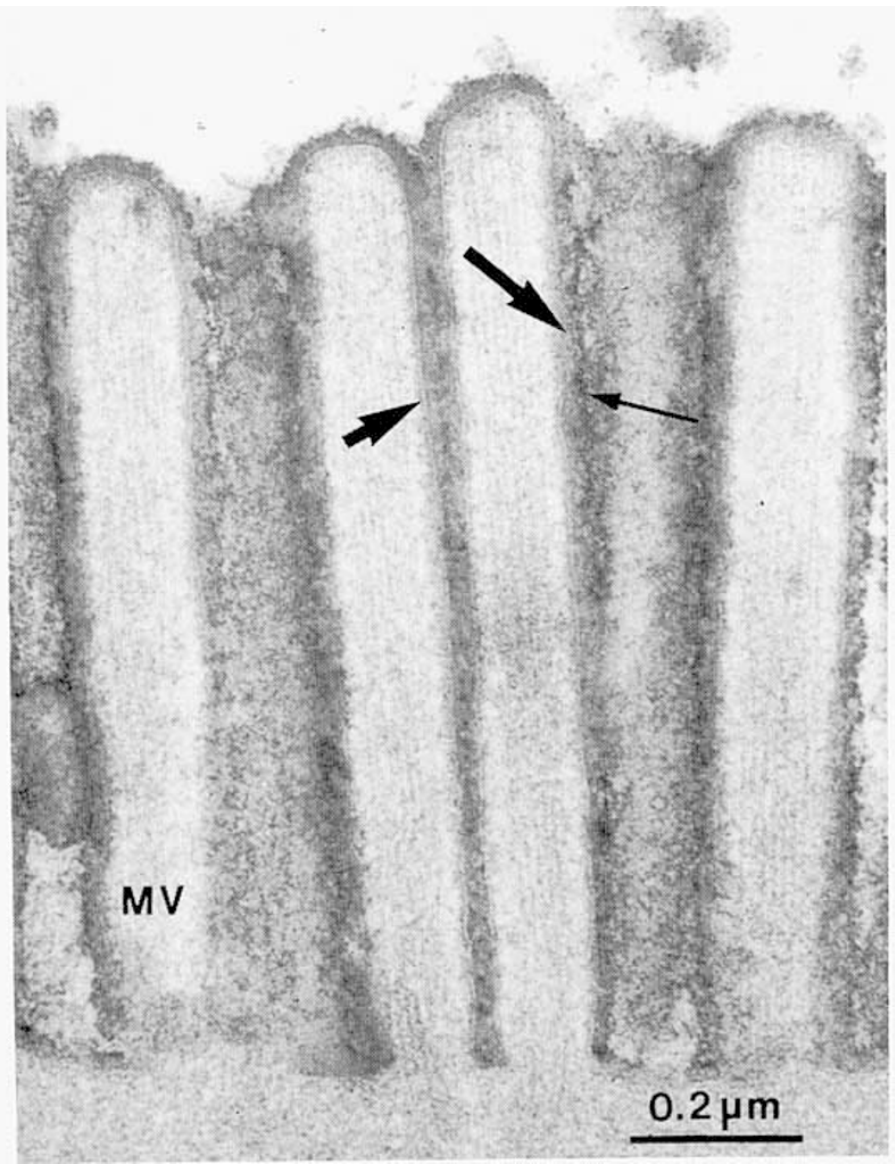

Fig. 2. Control patients (group I). On ultrathin sections stained with lead citrate, electron-dense deposits (short arrow) are visible outside the trilaminary membrane of the microvilli (MV). Thick arrow, inner part of the electron-dense deposits; thin arrow, outer part of the deposits $(\times 85,000)$.

abnormal (presence of double MV, variable diameter, and length). On the same enterocyte, MV larger than the controls next to smaller MV were observed. Electron-dense deposits were detected on a band running along the outside of the plasma membrane. As in the controls, two parts were sometimes visible in this band, but in most cases they were intermingled (Fig. 3). The thickness of electron-dense deposits varied according to the region $(19 \pm 6 \mathrm{~nm})$ (mean \pm S.D.) (Table 4). The electron-dense deposits along the membrane of each enterocyte were unevenly distributed: on a few MV the band was continuous but mostly it was discontinuous and lacked homogeneity. This was more obvious in subtotal than in partial VA. No significant difference in the MV length and electron-dense deposits thickness was observed between groups I and II. 


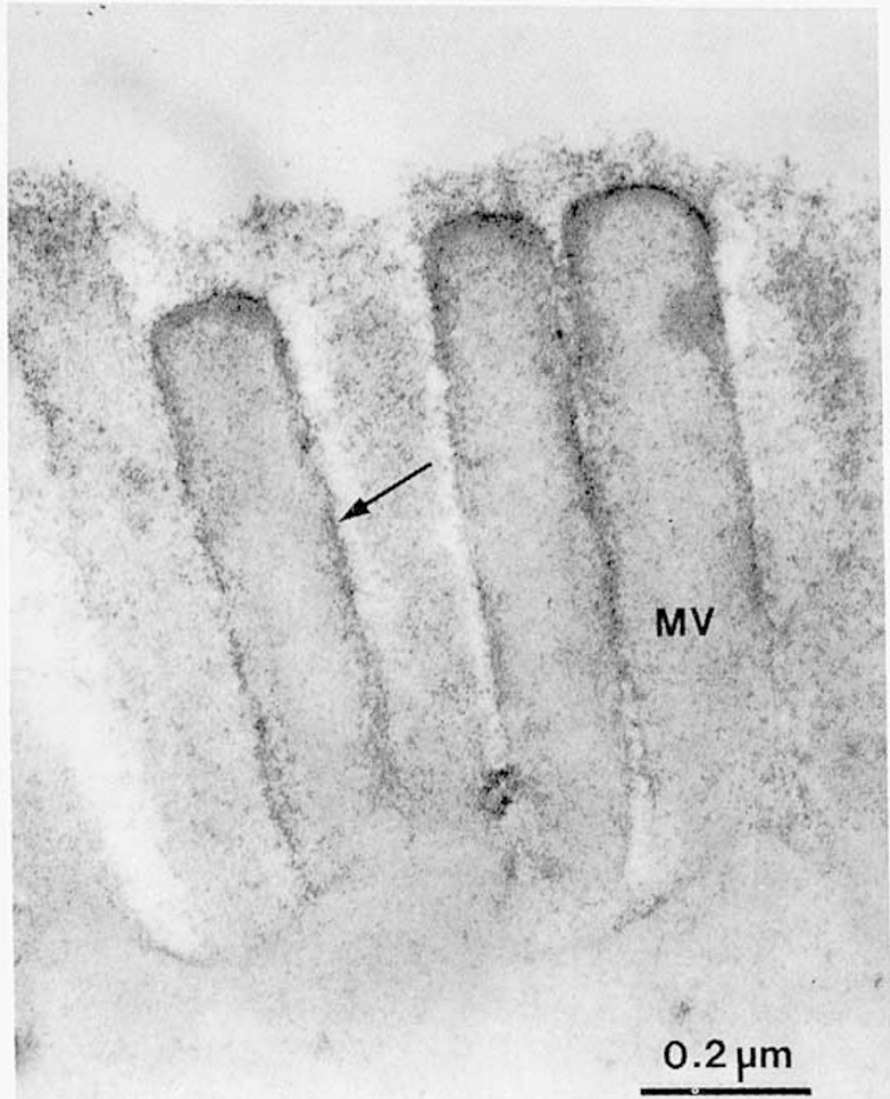

Fig. 3. Patients with villous atrophy (group II). Electron-dense deposits indicting concanavalin A surface receptors are visible (arrow) outside the microvilli (MV). However, their distribution is irregular in shape, unevenly spaced out over the membrane and the two parts of the band are intermingled (Ultrathin sections not stained with lead citrate) $(\times 85,000)$.

In group III, MV with a length of $1.25 \pm 0.32 \mu \mathrm{m}$ (mean \pm S.D.) were observed (Table 4). Their structure was normal or slightly damaged. Electron-dense deposits were found on an outer band running along the membrane. This band was also divided into two parts as in the controls and its thickness was $16 \pm 7 \mathrm{~nm}$ (mean \pm S.D.) (Table 4). A significant difference in the MV length and thickness of electron-dense deposits was observed between groups I and III $(p<0.01)$. On some MV the distribution of the electron-dense deposits along the membrane was uneven and sporadic. Their shapes were dissimilar heterogeneous as in group II (Fig. 4). On others, their distribution was even and continuous, as in group I (Fig. 5). No electron-dense deposits were observed on blocks incubated with peroxidase alone or in the Graham and Karnovsky solution for each group of patients.

\section{DISCUSSION}

The distribution of Con A surface receptors was studied on the top third of intestinal villi. Enterocyte agglutination has already been demonstrated with Con A by Podolsky and Weiser (16) on enterocytes from villi and crypts. In the present study, the presence of lectin was not shown in the crypts, perhaps because we incubated our material in blocks instead of examining isolated cells like Podolsky and Weiser. However, staining was regular in this top part of the villi and allowed us to study the most mature enterocytes. It is known that these cells are very rapidly destroyed in $\mathrm{CD}$, and they are probably the target of gluten toxicity $(11,27)$.

Localization of the electron-dense deposits next to the trilaminary membrane enabled us to assume that the Con $A$ receptors were situated on the glycocalyx as already demonstrated in other cell systems $(13,15)$. The division of the electron-dense deposits in two parts revealed the existence of two types of glycoconjugates in the BB glycocalyx: (1) glycoconjugates adhering to the membrane that probably formed part of the glycoproteins or glycolipids and were located in what may correspond to the internal homogeneous area; and (2) glycoconjugate farther on the membrane that resembled electron-dense external particles in appearance. Surface coat filaments were rarely visible and their absence might be due to their fragility during fixation of the biopsy.

The even distribution of Con $A$ receptors over the BB membrane in the controls (group I) suggests homogeneous glycosylation of the normal BB enterocytes. When VA was present (group II) we found severe structural abnormalities of the $\mathrm{BB}$, which were described earlier on routine electron microscopy $(20,21)$. In this group, the degree of irregularity of Con A receptor distribution corresponded to the degree of damage to the BB. There was no significant difference between groups I and II as regards the MV length and thickness of electron-dense deposits. These results are possibly explained by the variations observed in patients of group II. Similar irregularity in electron-dense deposits were also reported by Jos and DeTand (10) with other lectins. When we studied normalized mucosa from treated patients (group III), we found no significant structural abnormalities of the BB, but we noticed the MV were significantly longer than in the controls ( $P$ $<0.01)$. Con A binding sites were found to be irregular in shape and unevenly spaced out in some areas and normal in others. The electron-dense deposits were significantly thinner than in the controls $(P<0.01)$.

Those results suggest abnormal membrane glycosylation during $\mathrm{CD}$. The decrease in the glycosyltransferase activity of $\mathrm{BB}$ was observed by Weiser and Douglas (26) on normalized mucosa from

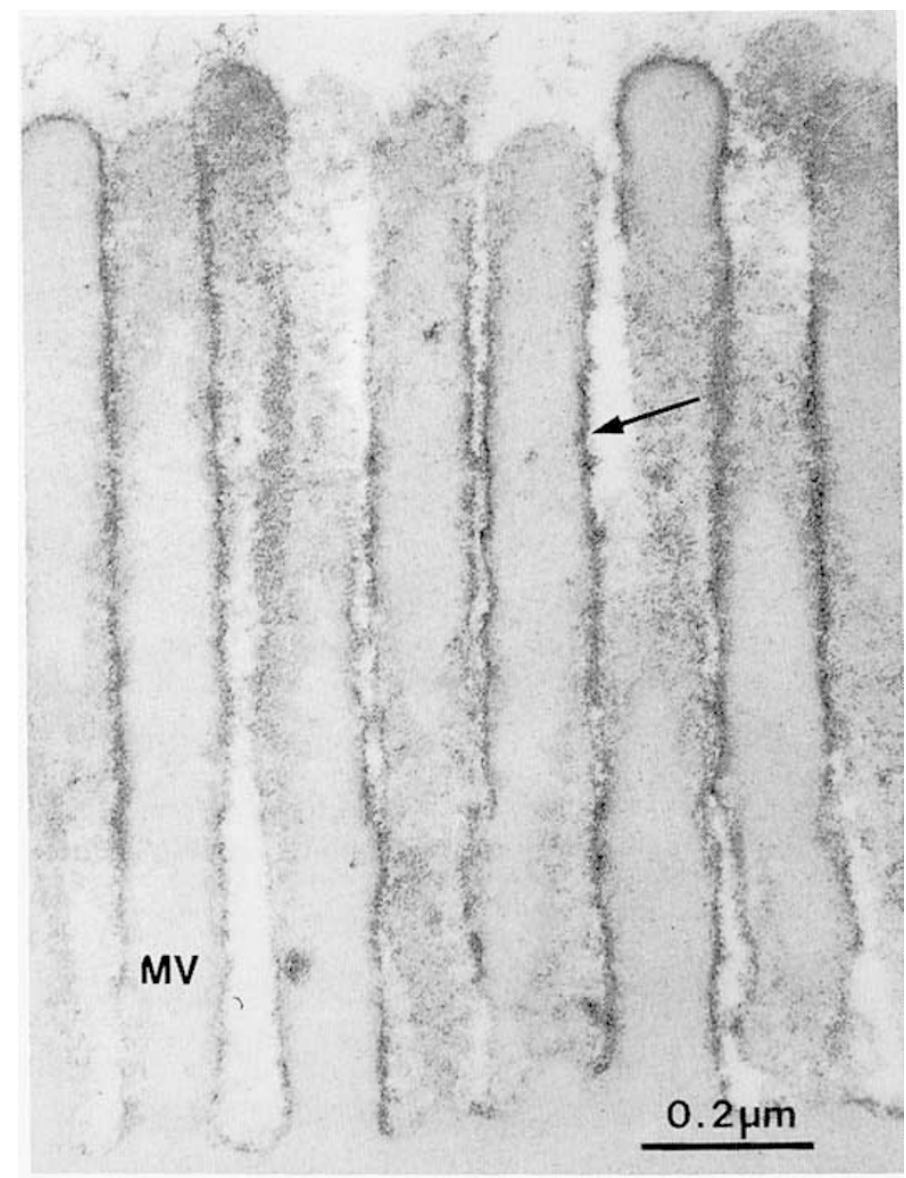

Fig. 4. Patients with normalized mucosa (group III). Distribution of electron-dense deposits is irregular in shape, sporadic and sparse (arrow). The two parts of the band of deposits are intermingled. The band is thinner than control. (MV, microvilli) (Ultrathin sections not stained with lead citrate) $(\times 85,000)$. 


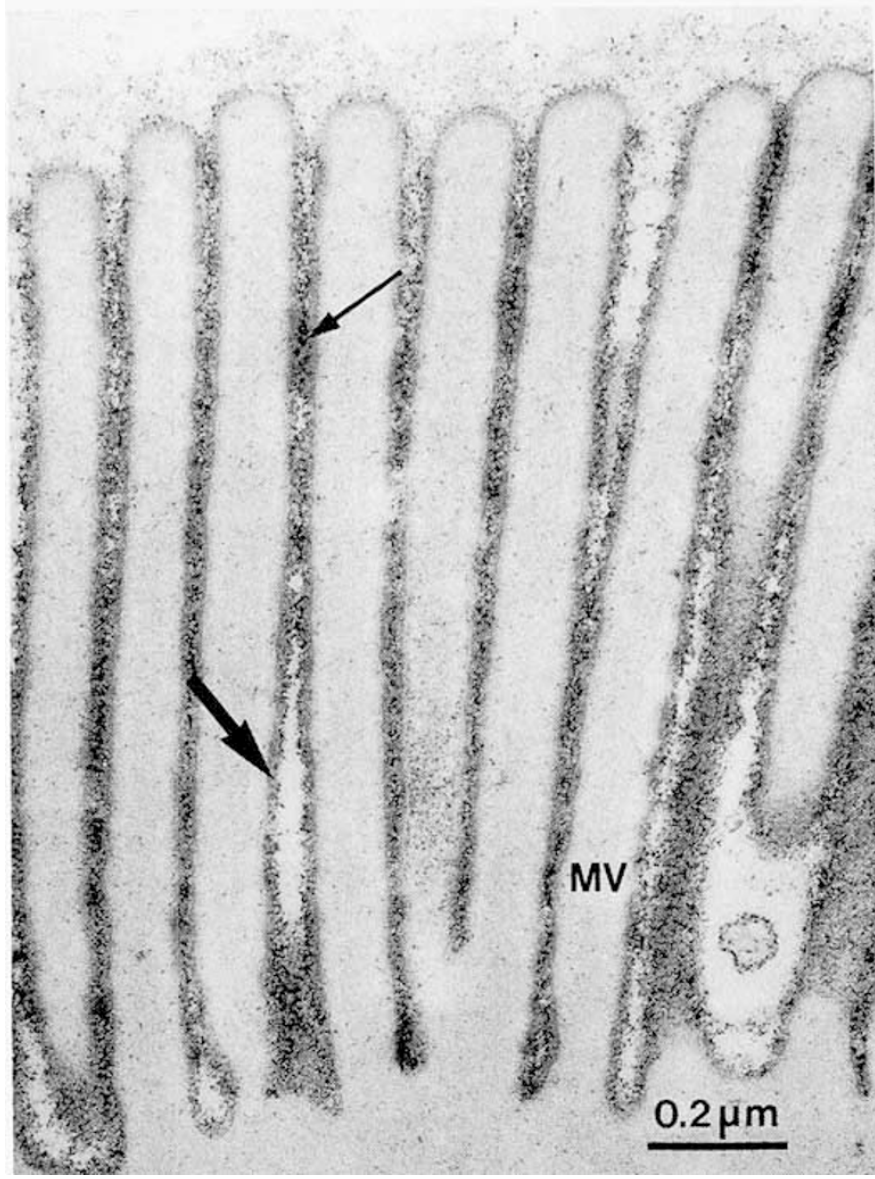

Fig. 5. Patients with normalized mucosa (group III). Distribution of electron-dense deposits is similar to that observed in control patients but microvilli (MV) are longer and the electron-dense band is thinner. Thick arrow, inner part of the electron-dense deposits; thin arrow, outer part of the deposits. (Ultrathin sections not stained with lead citrate) $(\times 70,000)$.

treated $\mathrm{CD}$. The same authors studied Con A affinity for BB enterocytes in an isolated cell system and noted that Con A agglutination increased on immature cells, a finding connected with a high level of galactosyltransferase activity (17). This possibly abnormal glycosylation is understandable during active $\mathrm{CD}$, when the structural abnormalities of the BB suggest that membrane synthesis may be hampered by the enterocytes. The decline in disaccharidase activity during VA has long ago been shown (18) and the membrane enzymes involved are glycoproteins. However, the persistence of possibly abnormal glycosylation in normalized mucosa is surprising. It might also be linked to some abnormality in membrane synthesis regulation, as suggested by the variations in MV length. Even if such abnormal glycosylation actually takes place, we do not know if it is due to gluten toxicity mechanism (presence of abnormal glycoproteins or glycolipids on the membrane) or to a nonspecific abnormality. Recently, intestinal transplantation was shown to cause changes in lectin binding sites, in the rat (5). This suggests that nonspecific intestinal disorders can alter membrane glycosylation. Our findings in patients with treated coeliac disease might reflect previous intestinal damage; in this case similar results could be obtained in other intestinal diseases involving VA, such as the intolerance of cow's milk protein.

\section{REFERENCES AND NOTES}

1. Araya, M. and Walker-Smith, J. A.: Specificity of ultrastructural changes of small intestinal epithelium in early childhood. Arch. Dis. Child., 50: 844 (1975).

2. Bernhard, W. and Avrameas, S.: Ultrastructural visualization by means of concanavalin A of cellular carbohydrate components. Exp. Cell Res., 64:232 (1971).

3. Douglas, A. P.: The binding of a glycopeptide component of wheat gluten to intestinal mucosa of normal and coeliac human subjects. Clin. Chim. Acta, 73: 357 (1976).

4. Fontaine, J.L. and Lasfargues, G.: Diagnostic de l'intolérance au gluten chez l'enfant après l'âge de dix-huit mois. In: Journées Parisiennes de Pédiatrie. $\mathrm{p}$ 112 (Flammarion, Paris, 1979)

5. Freeman, H. J., Etzler. M. E., Garrido, A. B., and Kim, Y. S.: Alterations in cell surface membrane components of adapting rat small intestinal epithelium; studies with lectins after massive proximal jejunoileal transposition. Gastroenterology, 75:1066 (1978)

6. Goldstein, I. J., So, L. L., Ynag, Y., and Callies, Q. C.: Protein carbohydrate interaction. J. Immunol., 103:695 (1969)

7. Graham, R. C. and Karnovsky, M.J.: The early stages of absorption of injected horseradish peroxidase in the proximal tubules of mouse kidney: ultrastructural cytochemistry localization by a new technique. J. Histochem. Cytochem., 14: 291 (1966).

8. Guillouzo, A. and Feldmann, G.: Surface and intracellular localization of concanavalin A binding sites in rat liver cells. J. Histochem. Cytochem., 25: 1303 (1977)

9. Ito, S.: Structure and function of the glycocalyx. Fed. Proc., 28: 12 (1969).

10. Jos, J. and DeTand, M. F.: Ultrastructural localization of lectin receptors in normal and coeliac intestinal mucosa. Acta Paediatr. Belg., 32:151 a (1979).

11. Lancet Editorial: The coeliac philosophy. Lancet, II: 501 (1974).

12. Luft, J. H.: The structure and properties of the cell surface coat. Int. J. Cytol.. 45 291 (1976)

13. Martinez-Palomo, A., Wicker, R., and Bernhard, W.: Ultrastructural detection of concanavalin surface receptors in normal and polyoma-transformed cells. Int. J. Cancer, 9: 676 (1972).

14. McNeish, A. S., Harms, H. K., Rey, J., Shmerling, D. H., Visakorpi, J. S., and Walker-Smith, J. A.: The diagnosis of coeliac disease: a commentary on the current practices of members of the European Society for Pediatric Gastroentrology and Nutrition (E.S.P.G.A.N.). Arch. Dis. Child., 54: 783 (1979).

15. Nicolson, G. L.: The interactions of lectins with animal cell surface. Int. Rev. Cytol., 39: 89 (1974)

16. Podolsky, D. K. and Weiser, M. M.: Specific selection of mitotically active intestinal cells by concanavalin A-derivatized fibers. J. Cell Biol., 58: 497 (1973).

17. Podolsky, D. K., Weiser, M. M., Thomas La Mont, J., and Isselbacher, K. J.: Galactosyltransferase and concanavalin A agglutination of cells. Proc. Natl. Acad. Sci. USA, 71: 904 (1974).

18. Rey, J., Schmitz, J., Rey, F., and Jos, J.: Cellular differentiation and enzymatic deficits. Lancet. I: 218 (1971).

19. Rubino, A.: Le défaut de peptidase dans la maladie coeliaque: la fascination des hypothèses. Arch. Fr. Pediatr., 35: 341 (1978).

20. Shiner, M.: Ultrastructure of jejunal surface epithelium in untreated idiopathic steatorrhoea. Brit. Med. Bull., 23: 223 (1967).

21. Shiner, M.: Electron microscopy of jejunal mucosa. Clinics Gastroenterol., 3: 33 (1974).

22. Stroeber, W., Falchuk, Z. M., Rogentine, G.N., Nelson, D. L., Klaeveman, H L.: The pathogenesis of gluten-sensitive enteropathy. Ann. Intern. Med., 83: 242 (1975).

23. Trier, J. S. and Rubin, C. E.: Electron microscopy of the small intestine: a review. Gastroenterology, 49: 574 (1965)

24. Trier, J. S., Falchuk, Z. M., Carey, M. C., and Shreiber, D. S.: Coeliac sprue and refractory sprue. Gastroenterology, 75: 307 (1978).

25. Weiser. M. M. and Douglas, A. P.: An alternative mechanism for gluten toxicity in coeliac disease. Lancet, I: 567 (1976).

26. Weiser, M. M. and Douglas, A. P.: Cell surface glycosyltransferases of the enterocyte in coeliac disease. Perspective in coeliac disease. In: Nicholl, B. M. L., McCarthy, C. F., Fottrel. P. F., p 451 (MTP Press Limited, Lancaster. 1978).

27. Wright. N., Watson, A.. Morley, A., Appleton, D., and Marks, J.: Cell kinetics in flat (avillous) mucosa of the human small intestine. Gut, 14: 701 (1973).

28. Requests for reprints should be addressed to: Dr G. Feldmann, Laboratoire d'Histologie, Embryologie, Cytogénétique, Faculté de Médecine Xavier-Bichat. 16 rue Henri Huchard, 75018 Paris, France.

29. The authors are grateful to Mrs A.M. Schneider for her help during the preparation of this work.

30. Received for publication December 29, 1980.

31. Accepted for publication October 16, 1981 . 